\title{
Detection of River Pollution Using Water Quality Index: A Case Study of Tropical Rivers in Penang Island, Malaysia
}

\author{
Mohd-Rosli Nurul-Ruhayu', Yii Jau An², Yahya Khairun'1,2* \\ ${ }^{1}$ Centre for Marine and Coastal Studies, Universiti Sains Malaysia, Penang, Malaysia \\ ${ }^{2}$ School of Biological Sciences, Universiti Sains Malaysia, Penang, Malaysia \\ Email: ruhayu rosli@yahoo.com, eric.yja@gmail.com, ${ }^{*}$ khairun@usm.my
}

Received 12 February 2015; accepted 27 February 2015; published 4 March 2015

Copyright (C) 2015 by authors and OALib.

This work is licensed under the Creative Commons Attribution International License (CC BY). http://creativecommons.org/licenses/by/4.0/

(c) (i) Open Access

\section{Abstract}

A study on the Water Quality Index (WQI) has been conducted among 11 rivers in Penang Island, Malaysia from October 2012 to January 2013. The water quality status of rivers was classified based on the Interim National Water Quality Standard (INWQS) for Malaysia. The six water quality parameters used to determine the water quality index are dissolved oxygen (DO), biological oxygen demand (BOD), chemical oxygen demand (COD), total suspended solid (TSS), ammonia and pH value. Based on the WQI assessment, among the 11 rivers studied, none of the rivers were considered as clean. The upstream and middle stream of the Pinang River in Balik Pulau (with WQI = 69 and 70 respectively), the upstream and middle stream of the Kongsi River (with $W Q I=67$ and 72 respectively) and the upstream of the Betong River (with $W Q I=63$ ) were slightly polluted, while the rest of the rivers had a WQI of below 60, which were categorized as polluted rivers. Among the 30 sampling stations, 17 stations were classified as Class III (extensive treatment of water supply required; fish for common economic value, species tolerance, and for livestock drinking), and 13 stations were classified as Class IV water status, which was classified as irrigation according to INWQS. From this study, the WQI and river classification system were considered as a tool for assessing the health status of river water quality. Efficient and sustainable management of rivers in Penang Island should be emphasized in order to protect their aesthetic value for future generations.

\section{Keywords}

Water Quality Index, Pollution, Rivers

Subject Areas: Environmental Sciences

\footnotetext{
${ }^{*}$ Corresponding author.
}

How to cite this paper: Nurul-Ruhayu, M.-R., An, Y.J. and Khairun, Y. (2015) Detection of River Pollution Using Water Quality Index: A Case Study of Tropical Rivers in Penang Island, Malaysia. Open Access Library Journal, 2: e1209. 


\section{Introduction}

Rivers are important in maintaining the balance of the ecosystem and are also a main source of water for humans and animals that live in the surrounding area [1]. Rivers also play an important role in assimilating or carrying away industrial or municipal wastewater, run-off from agriculture area, sewage from urban areas, and any other anthropogenic factors. Thus, they are vulnerable to pollution [2]. The Department of Environment (DOE) in Malaysia uses the Water Quality Index (WQI) to evaluate the status of river water quality. The WQI serves as the basis for river assessment in relation to pollution load categorization and the designation of classes of beneficial uses as provided under the Interim National Water Quality Standard (INWQS) for Malaysia [3].

In 2007, 1064 stations of river basins in Malaysia were monitored by the DOE. Out of these 1064 stations, $638(60 \%)$ were found to be clean, $376(35 \%)$ were slightly polluted, and $50(5 \%)$ were polluted. According to the DOE, the major pollutants are biological oxygen demand (BOD) ammonia and total suspended solid (TSS) [3].

In Penang Island, among the 31 rivers monitored, 4 rivers with 9 stations were categorized as clean, 9 rivers with 19 stations were categorized as slightly polluted, and 18 rivers with 29 stations were categorized as polluted in Penang [3].

The most commonly known pollutants in rivers are organic waste, heavy metals, suspended solids and chemicals such as herbicides and pesticides [4]. The agricultural area or agro-based industries use a lot of chemical materials such as chemical fertilizers, herbicides, and pesticides. Some of the factories discharge their untreated chemical waste directly into the river water. These pollutants, such as mercury, copper, cyanide, lead and other heavy metals, are toxic to the aquatic life in the rivers [5]. Deforestation activities are also closely related to river pollution. Forest acts as a water catchment area in an environment. It helps to recharge the underground water and the plant roots bind the soil tightly. As there is clearing and cutting down of forest, the land is no longer protected. Soil erosion can occur and the soil particles will flush into the nearby river [5]. The influx of large amounts of soil particles leads to high sedimentation in the river and increases the suspended solids in the river column [6].

The determination of water quality is important, because water is frequently being used in our daily life. The water quality measurement is aimed to make sure that the content of the water supply is safe to use. Water quality testing (i.e. study of the physical, chemical and biological characteristics of water) will give information about the healthiness of the waterways, whether it fulfills the requirements of biotic species to live or to be used by humans for various purposes [2] [7].

Therefore, WQI was developed to monitor the water quality changes in a particular area by the determination of 6 parameters (i.e. DO, BOD, COD, TSS, ammonia and $\mathrm{pH}$ ). The purpose of this study is to assess the health status of the selected rivers in Penang Island using the WQI, and also to classify the rivers according to the level of pollution index.

\section{Materials and Methods}

\subsection{Sampling Sites}

This study was conducted one-off collection from November 2012 to January 2013. The 11 rivers in Penang Island were selected based on their geographical location (Figure 1). Most of hotels are located at the northern part of the island. Meanwhile, urban development focuses along the eastern part. Agriculture, aquaculture and industries are more concentrated at the western and southern part of Penang. Three sampling stations from upstream (station 1 (S1)), middle stream (station 2 (S2)) and downstream (station 3 (S3)) were chosen based on accessibility to the sampling station. The Teluk Bahang River and the Batu Feringghi River are located in the north part of Penang Island, while the Teluk Kumbar River and the Bayan Lepas River are situated in the southern part of the island. The Pinang River in the Balik Pulau River, the Kongsi River, the Burung River and the Betong River in the western part of the island flow into the Strait of Malacca. The Pinang River in Georgetown, the Dua Besar River and the Keluang River in the eastern part of the island. These river are microtidal and very shallow with an average depth of $2-3$ meters.

\subsection{Water Sample Collection and Analysis}

The surface water samples with two replicates were collected and stored in a clean 500 milliliter polyethylene 

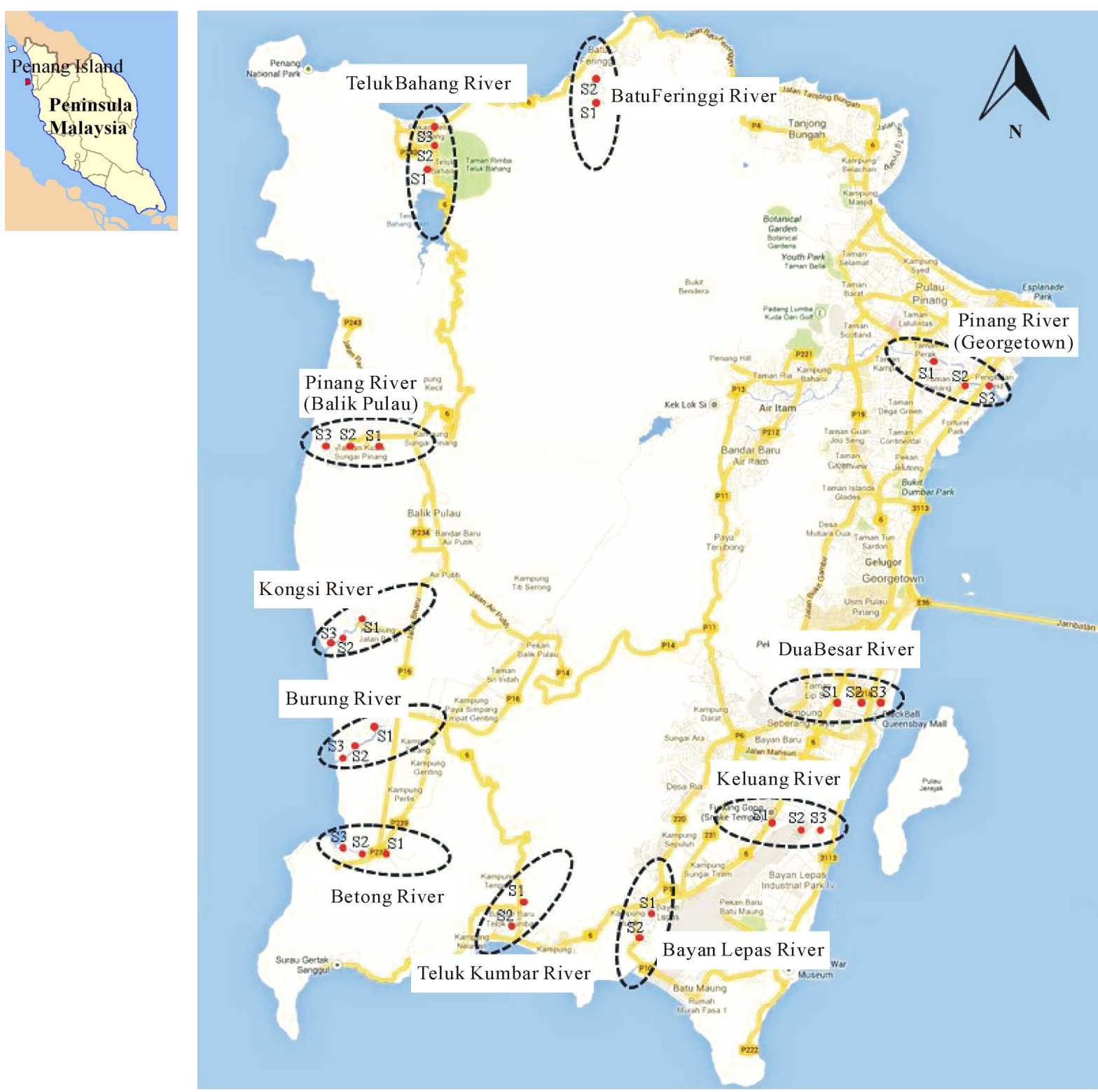

Figure 1. Locations of the selected rivers in Penang Island where S1 = upstream, S2 = middle stream and S3 = downstream.

bottle. Water samples were stored cold in an icebox to minimize microbial activity which may have affected the chemical contents of the water samples. For the BOD and COD analysis, 300 milliliter BOD bottles and small glass vials were filled with the water sample in the field. The environmental parameters such as $\mathrm{pH}$ and dissolved oxygen were measured in situ using a pH Scan and a DO meter YSI 52 respectively. In the laboratory, the water samples were used to measure TSS, ammonia and COD analysis using the [8] standard method. For BOD analysis, the bottles were incubated at 20 degree Celcius for 5 days, and then the BOD readings were measured with the BOD meter YSI 52.

\subsection{Calculation of the Water Quality Index (WQI)}

The water quality of the river is categorized into five classes, which are classes I, II, III, IV and V based on the WQI (derived from the determination of DO, BOD, COD, TSS and ammonia and $\mathrm{pH}$ ) (refer to Table 1), to determine whether the river water is clean, slightly polluted or polluted based on the WQI and INWQS. The WQI 
Table 1. Water Quality Index (WQI) and River Classification of Interim National Water Quality Standards (INWQS) (DOE, 2007).

\begin{tabular}{|c|c|c|}
\hline WQI & Class & Uses \\
\hline$>92.7$ & Class I & $\begin{array}{l}\text { Conservation of natural environment Water supply I—practically no treatment necessary } \\
\text { Fishery I-very sensitive aquatic species }\end{array}$ \\
\hline \multirow[t]{2}{*}{$76.5-92.7$} & Class IIA & $\begin{array}{l}\text { Water supply II-conventional treatment required } \\
\text { Fishery II-sensitive aquatic species }\end{array}$ \\
\hline & Class IIB & Recreational use with body contact \\
\hline $51.9-76.5$ & Class III & $\begin{array}{l}\text { Water supply III—extensive treatment required } \\
\text { Fishery III—common economic value and species tolerant: livestock drinking }\end{array}$ \\
\hline $31.0-51.9$ & Class IV & Irrigation \\
\hline$<31.0$ & Class V & None of the above \\
\hline
\end{tabular}

was calculated based on six parameters; namely the mean of DO, BOD, COD, TSS, ammonia and pH values [3]. The procedure of calculation consists of 3 steps: to identity sub-index (SI) equation based on the value of parameter, to calculate sub-index (SI) of every parameter, and to calculate water quality index. The formula is given below:

$$
\mathrm{WQI}=0.22 \mathrm{SI}_{\mathrm{DO}}+0.19 \mathrm{SI}_{\mathrm{BOD}}+0.16 \mathrm{SI}_{\mathrm{COD}}+0.16 \mathrm{SI}_{\mathrm{SS}}+0.15 \mathrm{SI}_{\mathrm{AN}}+0.12 \mathrm{SI}_{\mathrm{pH}}
$$

where SI refers to the sub-index for each parameter, and the coefficients are the weighting factors derived from the opinion poll. $\mathrm{SI}_{\mathrm{DO}}=\mathrm{Sub}-\mathrm{Index} \mathrm{DO}, \mathrm{SI}_{\mathrm{BOD}}=\mathrm{Sub}-\mathrm{Index}$ of $\mathrm{BOD}, \mathrm{SI}_{\mathrm{COD}}=\mathrm{Sub}$-Index of COD, $\mathrm{SI}_{\mathrm{SS}}=\mathrm{Sub}-$ Index of TSS, $\mathrm{SI}_{\mathrm{AN}}=$ Sub-Index of ammonia and $\mathrm{SI}_{\mathrm{pH}}=$ Sub-Index of $\mathrm{pH}$.

For this study, the WQI of each river zones (i.e. upstream, middle and downstream) were calculated.

\section{Results}

\subsection{Water Quality Index (WQI)}

The WQI equation is derived by applying the water quality data measured, and the condition of rivers water can be classified by referring the INWQS. The WQI and the river classification of INWQS and its usage are shown in Table 1.

According to Table 2, the selected rivers in Penang can be grouped into two classes: Class III and Class IV. Most of the upper stations showed Class III, which is considered polluted except for the Pinang River in Georgetown and the Dua Besar River. Five rivers, i.e. the Teluk Bahang River, the Betong River, the Pinang River in Georgetown, the Dua Besar River and the Teluk Kumbar River are polluted as they fall into Class IV river status at their middle stations, while others remain in Class III. Meanwhile, the Batu Feringghi River, the Betong River, the Pinang River in Georgetown, the Dua Besar River, the Teluk Kumbar River and the Bayan Lepas River were categorized as Class IV at their down streams.

\subsection{Statistical Analysis}

From the two-way ANOVA analysis, $\mathrm{pH}(\mathrm{p}<0.05)$ and DO $(\mathrm{p}<0.01)$ are shown significantly different with the region and river zonations (i.e. upstream, middle and downstream). The other variables (BOD, COD, ammonia and TSS) are not significantly different with the regions and river zonations.

Based on one-way ANOVA statistical test, there are significant differences $(\mathrm{p}<0.05)$ of BOD, COD, ammonia and $\mathrm{pH}$ among these 11 rivers. However, there is no significant difference $(\mathrm{p}>0.05)$ for DO and TSS with these selected rivers

\section{Discussion}

\subsection{Water Quality Index (WQI) of the Studied Rivers}

The Malaysian DOE has used the WQI to determine the status of river water quality and to identify the sources 
Table 2. Water quality status of the selected rivers in Penang Island.

\begin{tabular}{|c|c|c|c|c|c|}
\hline Region & River & Station & WQI & Class & WQ Status \\
\hline \multirow{6}{*}{ North } & \multirow{3}{*}{ Teluk Bahang } & 1 & 58.432 & III & $\mathrm{P}$ \\
\hline & & 2 & 49.765 & IV & $P$ \\
\hline & & 3 & 55.649 & III & $\mathrm{P}$ \\
\hline & \multirow{3}{*}{ Batu Feringghi } & 1 & $N A$ & $N A$ & $N A$ \\
\hline & & 2 & 54.172 & III & $P$ \\
\hline & & 3 & 50.326 & IV & $P$ \\
\hline \multirow{12}{*}{ West } & \multirow{3}{*}{ Pinang (Balik Pulau) } & 1 & 69.569 & III & SP \\
\hline & & 2 & 70.55 & III & SP \\
\hline & & 3 & 56.919 & III & $\mathrm{P}$ \\
\hline & \multirow{3}{*}{ Kongsi } & 1 & 67.275 & III & SP \\
\hline & & 2 & 72.417 & III & SP \\
\hline & & 3 & 58.965 & III & $\mathrm{P}$ \\
\hline & \multirow{3}{*}{ Burung } & 1 & 53.946 & III & $\mathrm{P}$ \\
\hline & & 2 & 58.095 & III & $P$ \\
\hline & & 3 & 54.938 & III & $\mathrm{P}$ \\
\hline & \multirow{3}{*}{ Betong } & 1 & 63.1 & III & SP \\
\hline & & 2 & 50.98 & IV & $P$ \\
\hline & & 3 & 36.845 & IV & $\mathrm{P}$ \\
\hline \multirow{9}{*}{ East } & \multirow{3}{*}{ Pinang (Georgetown) } & 1 & 46.158 & IV & $P$ \\
\hline & & 2 & 51.878 & IV & $P$ \\
\hline & & 3 & 51.534 & IV & $\mathrm{P}$ \\
\hline & \multirow{3}{*}{ Dua Besar } & 1 & 46.421 & IV & $\mathrm{P}$ \\
\hline & & 2 & 45.659 & IV & $\mathrm{P}$ \\
\hline & & 3 & 50.109 & IV & $\mathrm{P}$ \\
\hline & \multirow{3}{*}{ Keluang } & 1 & 57.097 & III & $\mathrm{P}$ \\
\hline & & 2 & 52.308 & III & $\mathrm{P}$ \\
\hline & & 3 & 55.358 & III & $\mathrm{P}$ \\
\hline \multirow{6}{*}{ South } & \multirow{3}{*}{ Teluk Kumbar } & 1 & $N A$ & $N A$ & $N A$ \\
\hline & & 2 & 49.987 & IV & $\mathrm{P}$ \\
\hline & & 3 & 48.423 & IV & $\mathrm{P}$ \\
\hline & \multirow{3}{*}{ Bayan Lepas } & 1 & $N A$ & $N A$ & $N A$ \\
\hline & & 2 & 52.14 & III & $\mathrm{P}$ \\
\hline & & 3 & 51.182 & IV & $\mathrm{P}$ \\
\hline
\end{tabular}

$\mathrm{C}=$ clean; $\mathrm{SP}=$ slightly polluted; $\mathrm{P}=$ polluted; $N A=$ not available due to difficult in accessibility to upstream. 
of pollution since 1978 [3]. In 2010, a total of 1055 water quality monitoring stations located at 570 rivers were monitored. Out of these 1055 monitoring stations, 527 (50\%) were found to be clean, 417 (40\%) slightly polluted and $111(10 \%)$ polluted [3]. The decrease in the number of clean rivers were attributed to an increase in the number of polluting sources such as sewage treatment plants and agro-based industries which contributed to a high pollution loading [3].

In this study, most rivers showed a low WQI from upstream until downstream. These rivers are mostly located in the eastern and southern regions of Penang Island. Meanwhile, the rivers that are located in the eastern region are the Pinang River in Georgetown and the Dua Besar River. The land-use in the eastern region is mainly for commercial areas, residential areas and some industrial areas [2]. The main source of pollution of the rivers in the eastern region is domestic sewage, waste from animal farming areas and industrial waste. Besides that, soil erosion from construction areas and surface run-off also cause river pollution [2]. All the stations of Pinang River in Georgetown and the Dua Besar River were considered as polluted, based on the classification of the water quality index by DOE. These rivers are also classified as Class IV, being very polluted, which meant that water use is only for irrigation purposes, based on the INWQS river classification.

The southern region of Penang Island is mainly residential and commercial areas, and has more industrial zones than other parts of Penang Island. The Keluang River, the Teluk Kumbar River and the Bayan Lepas River are located in this region. A total of seven stations from these three rivers are polluted based on the WQI results. All stations in the Keluang River and S2 (middle stream) in the Bayan Lepas River were classified as Class III (for common use, of economic value, species tolerant, livestock drinking) based on the INWQS river classification, while S3 (downstream) in the Bayan Lepas River and all stations on the Teluk Kumbar River were classified as Class IV. The causes of degradation of river water quality were caused by rapid development in urbanization and industrialization in the southern region of Penang Island [9].

Generally, the WQI of rivers in Balik Pulauare higher than the other rivers in Penang Island. The western region of Penang Island has cleaner river water because this region is less populated and less developed compared with others region of Penang. The western region of Penang Island is an agricultural zone. The rivers that were monitored in the western region were the Pinang River in Balik Pulau, the Kongsi River, the Burung River and the Betong River. Upper and middle stream in the Pinang River in Balik Pulau and the Kongsi River, and upper stream in the Betong River showed the rivers were slightly polluted. The whole stretch of Burung River, i.e. from upper until downstream parts, was classified to be polluted. The pollution of the rivers in this region is mainly caused by agricultural activities, domestic waste from residential areas and effluent from aquaculture activities [10] [11]. All human waste and aquaculture effluent are directly discharged into the river, and especially into the Pinang River [10] [12]. The excess fertilizer in the agriculture fields leached into the river water systems, causing high ammonia levels in the river water [13]. Fishing activities also play a main role, which causes high turbidity in the river; thus the rivers at the downstream parts have low WQI [14].

The northern region is the tourist region of Penang Island. The rivers that were monitored in this region were the Teluk Bahang River and the Batu Feringghi River. All the stations among these three rivers showed a polluted status under Class III, except for middle stream in the Teluk Bahang River and downstream in the Batu Feringghi River. The main source of pollution in the northern region is sewage and discharge of waste water without proper water treatment. An increased number of hotels and resorts along Batu Feringghi beach have increased the discharge of waste water into the surrounding rivers. The waste water becomes trapped in drains or rivers during high tide. Besides that, the Teluk Bahang River is also affected by fishing activities as the waste from the fishing industry is directly discharged into the river [15].

\subsection{Limitations of the Water Quality Index (WQI)}

The WQI classification proposed by the DOE in Malaysia is based on six parameters i.e. DO, BOD, COD, TSS, ammonia and $\mathrm{pH}$, differing from the WQI, which was developed by the National Sanitation Foundation (NSF). The WQI developed by the NSF monitors the WQI based on nine parameters i.e. temperature, $\mathrm{pH}, \mathrm{DO}$, turbidity, fecal-coliform, BOD, phosphate, nitrate and TSS. The range of WQI based on the NSF is classified as very bad, bad, medium, good and excellent. Most of the WQIs in use today are developed based on the NSF method [16].

The WQI is suitable for use as a reference, but it did not represent the real condition of the water status of the rivers as it has many limitations. The WQI did not reflect other pollutants such as heavy metals, hydrocarbons and other nutrients. The WQI is useful information for public and legislative policy-makers, but it is not suitable 
for technical and scientific applications because it does not carry enough information about the reality of the water status. There are some common limitations in the current WQI methods being used; rivers having a good WQI score does not mean they are free from pollution as they may still be affected by the parameters that are not included in the index calculation [17].

The assessment of the WQI method by the DOE in Malaysia is physio-chemical based; it does not include biological parameters to determine the microbes present in the water such as coliform and other types of bacteria. The microbiological contamination of rivers is becoming an issue for drinking water in developing and developed countries because it has brought health impacts to the residents. Hence, an assessment of microbes should be considered as one of the parameters in WQI indices. There are also some countries that do not have biological parameters in their own WQI, such as India, Iraq, Mexico and Nigeria. Countries which include biological parameters in their WQI are the United States, Europe, Canada and Iran [18].

\section{Conclusions}

The results showed that almost all the rivers in Penang Island were slightly polluted or polluted. The major point sources that cause the pollution of the rivers in Penang Island are domestic sewage and surface run-off. The waste from surrounding communities flows into the rivers, causing degradation of river water quality, especially for the rivers in the eastern and western regions of the Island. The waste water from industrial, residential and commercial areas should be processed and treated before being released into the river.

The WQI by the DOE in Malaysia is a useful tool to determine the status level of river water, but it has some limitations such as a lack of biological parameters and not representing all the information about the rivers' status. Parameters such as fecal coliform, heavy metals, oil and grease should be included in the WQI for Malaysia to get a more accurate reading of the real status of the river water. Therefore, suitable methods and management can be taken to improve the status of the rivers.

\section{Acknowledgements}

This research was funded by the Research University Grant (1001/PBIOLOGI/811210) from Universiti Sains Malaysia, Penang, Malaysia. We also want to express our sincere gratitude to the World Federation of Scientist for awarding the scholarship to conduct this research.

\section{References}

[1] Phillips, J.D. (1989) An Evaluation of the Factors Determining the Effectiveness of Water Quality Buffer Zones. Journal of Hydrology, 107, 133-145. http://dx.doi.org/10.1016/0022-1694(89)90054-1

[2] Farah Naemah, M.S., Nik Norulaini, N.A.R., Mohd Omar, A.K. and Fatehah, M.O. (2000) Identification of Pollution Sources within the Sungai Pinang River Basin. Project Report. Universiti Sains Malaysia, Penang, 478-485.

[3] DOE (Department of Environment) (2010) River Water Quality Monitoring. Department of Environment Malaysia, Ministry of Science, Technology and the Environment, Putrajaya.

[4] Fulazzaky, M.A., Seong, T.W. and Masirin, M.I.M. (2010) Assessment of Water Quality Status for the Selangor River in Malaysia. Water, Air and Soil Pollution, 205, 63-77. http://dx.doi.org/10.1007/s11270-009-0056-2

[5] DID (Department of Irrigation and Drainage) (2009) Study on the River Water Quality Trends and Indexes in Peninsular Malaysia. Department of Irrigation and Drainage, Ministry of Agriculture, Kuala Lumpur.

[6] Lim, F.L. (2007) Comparison of Water Quality Index (WQI) between DOE Method and Harkin's Index. Ph.D. Thesis, Universiti Teknologi Malaysia, Johor Bahru.

[7] Hector, R.A., Manuel, C.C., Rey, M.Q., Ruben, A.S. and Adan, P.M. (2012) An Overall Water Quality Index (WQI) for a Man-Made Aquatic Reservoir in Mexico. International Journal of Environmental Research and Public Health, 9 , 1687-1698. http://dx.doi.org/10.3390/ijerph9051687

[8] APHA (American Public Health Association) (2012) Standard Methods for the Examination of Water and Waste Water. American Public Health Association, Washington DC.

[9] Ibrahim, A.L. (2002) The Impact of Urbanization and Industrialization on River Water Quality: A Case Study of Sungai Kluang, Bayan Lepas, Pulau Pinang. In: Chan, N.W., Ed., River 99: Towards Sustainable Development, Universiti Sains Malaysia, Penang, 192-193.

[10] Nurul Ruhayu, M.R. (2011) The Impact of Anthropogenic Activities and Other Related Factors on Water Quality of 
Tropical River, Pinang River, Balik Pulau, Penang. Impak Aktiviti Antropogendan Faktor yang Berkaitan Terhadap Kualiti Air Sungai Tropika, Sungai Pinang, Balik Pulau, Pulau Pinang. M.Sc. Thesis, Universiti Sains Malaysia, Penang.

[11] Nurul Ruhayu, M.R. and Khairun, Y. (2012) Assessment of Nutrients and Sediment Loading in a Tropical River System in Malaysia. International Conference on Environment, Chemistry and Biology, IACSIT, Singapore, 49, 75-79.

[12] Khairun, Y., Nur Munira, A., Nurul Ruhayu, M.R. and Arif Chowdhury, Md. (2012) Coastal Aquaculture Effluent Quality and Environmental Management for Healthy Coastal Ecosystem-A Case Study of Pinang River, Balik Pulau in Penang Island, Malaysia. Asia-Pacific Journal of Rural Development, 22, 1-10.

[13] Azyana, Y., Nik Norulaini, N.A. and Nurul Jannah, H. (2012) Land Use and Catchment Size/Scale on the Water Quality Deterioration of Kinta River, Perak, Malaysia. Malaysian Journal of Science, 31, 121-131.

[14] Cheong, H.L. (2007) Penaksiran Kualiti Air di Muara Sungai Paya Bakau di Kawasan Balik Pulau. Assessment of Water Quality at the Mangrove Estuary in Balik Pulau Area. B.Sc. Thesis, Universiti Sains Malaysia, Penang.

[15] Poh, W.P. (1990) Coastal Resources Management: Tourism in Peninsular Malaysia. ASEAN Economic Bulletin, 7, $213-$ 221. http://dx.doi.org/10.1355/AE7-2F

[16] Chaturvedi, M.K. and Bassin, J.K. (2010) Assessing the Water Quality Index of Water Treatment Plant and Bore Wells, in Delhi, India. Environmental Monitoring and Assessment, 163, 449-453. http://dx.doi.org/10.1007/s10661-009-0848-2

[17] Hallock, D. (2002) A Water Quality Index for Ecology's Stream Monitoring Program. Washington State Department of Ecology, Olympia.

[18] Ramani Bai, V. (2009) Importance of Biological Parameters of Water Quality to Reform Water Quality Index in Practice. Advances in Environment, Computational Chemistry and Bioscience, 199-204. 